PROSE

\title{
Moment of Truth
}

\author{
Wayne Stellini
}

DAmien SAT NERVOUSLY in the corner, facing the empty white wall, meditating on the events that had led to his present situation. He knew that contemplating what could've been was a cruel game and one best not playing. Not now, anyway.

He wanted to turn around, see if there was any notable activity behind him, anything that would be of concern. Was his bag being checked? Were his possessions being examined, sprawled across a table for close inspection? Were notes being taken about him? Would he be presented with a dossier so damning that he would look like nothing less than a criminal mastermind?

If only he had gotten away with it ...

It was, he had to admit, simply the most immaculate thing he had ever laid eyes on. Impulse had gotten the better of him and had clouded his judgement. Not that he was impulsive by nature. That particular characteristic belonged to his older brother, though Damien could just hear his mother back home now: "You know, Graig never gives us this much trouble."

He should've known better of course, but dammit, he wasn't ready to admit guilt or defeat. He had a breaking point, as with all men, and surmised that the woman keeping a watchful eye on him would use any display of vulnerability to her advantage. She would strike like a merciless viper.

Feeling her eyes burning the back of his neck, he knew that the woman was observing his every move. He had allowed himself to trust 
her, feel protected by her presence, even considered her both ally and advocate. She had gained his confidence the entire morning and by the early afternoon Damien genuinely believed that the woman was alright.

He felt a little foolish, embarrassed by it all now, but of course she hadn't given any indication of the malevolence that was currently being displayed. Maybe she was making an example out of him? Some sort of scapegoat, perhaps, for all of those who'd wronged her in the past? But he wouldn't let her get her way. The woman played a wicked game, having betrayed his immediate loyalty. Damien had to stay strong, resilient, and knew that - in order to win - he'd have to put on his best performance when help arrived.

Eventually the woman approached him, her eyes still burning the back of his neck. "Are you ready to tell me your side of the story?"

"I told you already," he mumbled scornfully, refusing to turn and face her. "I took nothing!"

"I don't believe you."

"I don't care."

"Well, maybe you should," she hissed.

He had pissed her off now. He could tell that the woman's face had intensified, that she had become enraged by his insubordination, feeling the heat radiating off the old hag's ugly mug. He kept telling himself that help was on the way, that everything would soon be okay.

But the woman wouldn't let up. She spoke again, hissing like a vicious serpent; every word accompanied by a slight spray of saliva that hit the back of his neck. "Do you think that you're making things any better for yourself by being so rude?" When he refused to answer, she added, "Don't you think the truth will help?"

Despite her efforts to demoralise him, hope surged within when he could see, from the corner of his eye, that help had finally arrived. You're here! Dammit, you're here!

The burden of the woman's interrogation lifted from him, and Damien felt his entire body relax, giving him the confidence to smile.

He wanted to jump out of the chair and run towards the door, but knew that he had to let diplomacy take its course. The woman was a wicked creature, and Damien knew that his release wouldn't necessarily be a straightforward procedure, as she clearly wasn't someone who was easy to negotiate with. She seemed to enjoy having him there, but Damien knew corruptibility went hand-in-hand with authority. Maybe 
she could be bribed? Why hadn't he thought of that before? He'd have to let the expert deal with her.

Dressed in a light grey suit with black briefcase in hand, The Man entered and examined the room. The woman immediately approached him with the same broad smile and friendly tone that she had greeted Damien with earlier that morning.

Don't be fooled by her!

"Good afternoon," he said politely. "I'm here about Damien."

"Good afternoon, Mr. Thorn." The woman maintained a forced smile.

Perfidious bitch.

"We seem to have a problem here," he said.

Damn, he's good at playing nice.

"Yes we do," the woman agreed, crossing her arms.

You clearly have no idea who you're dealing with, Fudas!

"Um, on the phone you said something about a car?"

"He was caught red-handed, Mr. Thorn," the woman told him bluntly.

"Oh, I see." The Man rubbed his thumb and forefinger against his chin.

We've known one another for five years! Do you honestly think he'll disregard all of that trust and loyalty, and let you have your way? He'll make sure I'm out of here in no time, and then I'll never have to come back here again. Never. Ever. Fust you wait and see. . . you'll be the one apologising to me, lady!

The Man took a deep breath and approached the apprehended. "Hey."

"Hey," Damien repeated softly, getting a little emotional at seeing such a friendly, familiar face.

The Man - tall, broad, strong - put his hand on the detainee's shoulder, encouraging him to fully turn around and face the room, now only populated by three. It was full several minutes ago. Full of people, noise and activity. The area looked so much more spacious now. Everything was so still, so quiet. "Talk to me about this car." The Man took off his glasses and rubbed his eyes. He looked as though he'd had a long day of dealing with people. "I just want the truth. Nothing's so bad that we can't fix it."

Damien looked into The Man's tired eyes. He had wanted to put on a performance, deny it all and walk away scot free, victoriously clicking his heels in the air. But he couldn't. He just couldn't lie to him. He'd be more than happy to mislead and manipulate the woman, but The Man ... 
The Man was different. Special. The Man was always right and Damien's moment of truth had finally arrived. No, he couldn't do it. He couldn't fake a sorrowful emotion; make up a story. No, not to The Man.

"I'm sorry," he said remorsefully.

"Sorry you lied or sorry you got caught?" the woman asked.

The Man turned to her and said, "With all due respect, I'm doing just fine here. We'll have this resolved soon."

Teah, shut up, you loveless harridan. "I took the car," Damien confessed shamefully.

The Man turned to her and asked, "Where is it now?"

"With its rightful owner."

It was an ugly jalopy anyway.

The Man rubbed his chin again and, after some deep consideration, said, "Listen, Damien. I want you to write a letter of apology."

"OK." It sounded like a reasonable thing to do.

But then The Man added, "And to show how sorry you are, I want you to give up one of your own cars."

"What? No," he protested.

"What about your whole Matchbox collection instead?"

"No, Daddy," Damien groaned.

"Good. I think we've come to an agreement then."

The Man's tough but fair. He'd just give the kid one of his crappy cars, anyway. A wheel's missing on the blue convertible...

"Not a good way to start your first day of school, is it?" the woman said.

Damien didn't want to talk to the spinster.

"Your teacher's speaking to you, son."

"No, Miss Cuthbert," he sulked.

The Man then said, "I think we'll do better tomorrow."

Damien nodded. Even though he'd sworn to himself that he'd never return, it was obvious that The Man wanted him to.

"I hope so," the woman said with less optimism than the boy's father.

"Is there anything else that Damien needs to do to resolve this issue?"

Why'd you ask her that for? I thought you were on my side? She's a vicious beast! Don't you know that she'd have me in her servitude forever if she could?

"I think the punishment you've prescribed is sufficient, Mr. Thorn."

Phew!' She's clearly too afraid to push her luck. Thank God The Man's here. Let that be a lesson to you, Fezebel! 
"Well, then. I think Damien and I will be off home now." The Man ruffled his son's hair - oh, he loved it when his father did that - and added, "Say bye to your teacher and apologise for being so disruptive."

Damien wanted to protest the order, but The Man had gotten him out of a sticky situation with minimal fuss, so it was the least he could do. "I'm sorry."

"I'll see you tomorrow," she said. "I think we'll both enjoy a fresh start. I hope there won't be any more instances like this. Grade Prep is all about learning and playing, and having fun at the same time."

Damien nodded, offering his most exaggerated smile. He couldn't agree with her more.

Yeah, Grade Prep really is about having fun. Just wait until I get you back, you monstrous cow! Then we'll see who's having fun ... . 